\title{
A Shadow over Western Democracies
}

China's Political Use of Economic Power

\section{Wu Guoguang}

\section{OpenEdition}

\section{Journals}

Electronic version

URL: http://journals.openedition.org/chinaperspectives/4810

DOI: 10.4000/chinaperspectives.4810

ISSN: 1996-4617

\section{Publisher}

Centre d'étude français sur la Chine contemporaine

\section{Printed version}

Date of publication: 1 June 2009

Number of pages: 80-89

ISSN: 2070-3449

Electronic reference

Wu Guoguang, "A Shadow over Western Democracies », China Perspectives [Online], 2009/2 | 2009 Online since 01 June 2011, connection on 28 October 2019. URL : http://journals.openedition.org/ chinaperspectives/4810; DOI : 10.4000/chinaperspectives.4810

This text was automatically generated on 28 October 2019

(c) All rights reserved 


\title{
A Shadow over Western Democracies
}

\author{
China's Political Use of Economic Power
}

Wu Guoguang

\section{ABSTRACTS}

This paper investigates how China's success in economic development negatively influences civil liberties and democracy as practiced in the West, and asks why the growing economic interdependence between China and the global economy enables China to intervene in the political conduct of leading democracies but not vice versa. Empirically, the paper examines cases of Chinese foreign relations behaviour in which China uses its economic connections with various leading industrial democracies to bend their international political behaviour regarding visits by the Dalai Lama. It also highlights how economic interests relating to the chinese market make multinational corporations vulnerable to Beijing's political pressure, and analyses why international capital is easily lured to cooperate with the Chinese repressive state to curb freedom in and outside China. It argues that the new political economy of globalisation in the post-Cold War era explains the rise of this kind of dictator's diplomacy, and that postTiananmen China has greatly contributed to the shaping of a new political economy characterised by state-market collaboration in promoting material prosperity. 
AUTHOR

WU GUOGUANG

Chair in China and Asia-Pacific Relations at the Centre for Asia-Pacific Initiatives, University of Victoria, Canada. 